\title{
The Role of Women in the English Reformation illustrated by the Life and Friendships of Anne Locke
}

\author{
PATRICK COLLINSON \\ Lecturer in Ecclesiastical History, King's College, University of London
}

7 HE notable part played by women in the Reformation has rarely been given its due recognition in English historical 1 studies. In recent years Professor Wallace Notestein has written with characteristic authority and grace on 'The English Woman, $15^{80-1650,}{ }^{1}$ but one does not learn from this essay that the English women of this age had any religious propensities at all. And leaving aside the more prominent figures such as Queen Catherine Parr, Lady Jane Grey, and Catherine Brandon, duchess of Suffolk, women make but few appearances in most accounts of the English Reformation. This is no doubt only one symptom of the tendency of so many of our histories to dwell upon the officially inspired aspects of the Reformation to the neglect of the spontaneous and the local; to be concerned with the making of settlements and their enforcement rather than with the means by which Protestantism actually spread in families, towns, and other communities. And of course there are special factors which obscure the female contribution to history, the legal disabilities of the sex, which so often hide the married woman and allow us to catch glimpses only of the widow, a 'person' in law. Yet in France, where by the nature of the case a more sensitive historical criticism has had to be directed towards what Americans might call the grass-roots of Protestantism, the supreme importance of women in its propagation has not been missed. Professor Romier, for example, has written: 'Plus on étudie les commencements de la Réforme dans les provinces, plus l'action

1 In Studies in Social History : A Tribute to G. M. Trevelyan, ed. J. H. Plumb, I955, 69-107. 


\section{The Role of Women in the English Reformation}

féminine y apparaît considérable... C'était le plus souvent par les femmes, mères ou épouses, que la Réforme gagnait les familles de l'aristocratie et du peuple...' And he notes 'un zèle enflammé et une inflexible ténacité' in 'les huguenotes.' ${ }^{1}$ In England, studies devoted to Elizabethan Roman Catholicism, an analogous movement of unauthorised religious idealism, have for long recognised that the staunchest and most zealous recusants were often women.

But the same observation was often made of the more fervent Protestants by their contemporaries. When vestiarian conformity was first enforced on the London clergy in 1566 it provoked more than one female riot, and Bishop Grindal was 'howtyd at' in one church with cries of 'ware horns,' 'especially the wymen.' " And at the end of the reign the diarist Manningham described the principal puritan auditory of St Anne's, Blackfriars, as 'a great congregacion, specially of women,' wealthy and fashionably dressed women according to another, hostile observer. ${ }^{3}$ Richard Hooker notes that 'most labour hath been bestowed' among the Puritans 'to win and retain towards this cause them whose judgments are commonly weakest by reason of their sex,' and this, he believes, because women are naturally 'propense and inclinable to holiness.' Moreover, they are characterised by 'the eagerness of their affection, that maketh them, which way soever they take, diligent in drawing their husbands, children, servants, friends and allies the same way.' The Puritans knew how to exploit both good and bad feminine qualities. Their 'natural inclination unto pity' makes women more bountiful towards needy preachers than their husbands. And even their tendency to gossip may be put to good use, for women are marked by the 'singular delight which they take in giving very large and particular intelligence, how all near about them stand affected as concerning the same cause.' 4

These judicious remarks may serve instead of any general discussion of why women have sometimes been inclined to an intensity of religious enthusiasm not so often found in their husbands, a problem which lies beyond my present scope and my competence.

\footnotetext{
${ }^{2}$ Lucien Romier, Le Royaume de Catherine de Médicis: La France à la Veille des Guerres de Religion, Paris I 922, II, 234-40.

- The Remains of Archbishop Grindal, ed. William Nicholson, Parker Society 1843 , 288-9; Three Fifteenth-Century Chronicles, ed. J. Gairdner, Camden Society n.s., XXVIII (1880), I40.

SThe Diary of John Manningham, r602-3, ed. John Bruce, Camden Society, XcIx (1868), Ior, 74-5.

- Works, ed. J. Keble, revised R. W. Church and F. Paget, 1888, 1, 152-3.
} 


\section{Studies in Church History $-I I$}

But we may note in passing two factors which may help to account for the strong force of attraction which undoubtedly drew together English protestant divines and women of the higher ranks of society, the one theological and pastoral, the other social. These women belonged to a Church which had only recently abandoned the regular practice of spiritual direction, while laying great emphasis on the doctrine of election, which most of these ladies seem to have found perplexing. From the 'godly and comfortable letters' which the preachers addressed to them it is apparent that women sought assurance on this matter especially, and that they leant on the preachers as a Catholic would lean on his confessor. Thomas Cartwright writes to one of his female correspondents in the 'fearefull temppest' of her perplexities. ${ }^{1}$ Most of such letters can be reduced to one simple exhortation: 'Most hartilie I beseech you, good madam, goe on forward and faint not in the course of godlines.' 2 The preacher 'Thomas Wilcox corresponded in this vein in the 1570 s with the countess of Bedford, the countess of Sussex (foundress of Sidney Sussex College), Lady Anne Bacon, Lady Walsingham, Lady Mary Grey, and other ladies. ${ }^{3}$ Secondly we must remember that some of these gentlewomen and merchants' wives had received a liberal education and that many enjoyed a degree of personal liberty which were shining achievements of the society to which they belonged. The erudition of a number of choice girls of the generation of Lady Jane Grey perhaps needs no emphasis, but one is inclined to forget how liberal the treatment of women in general could seem to the eye of a foreign observer. The Dutchman Van Meteren noted that when not engaged in managing their households, English middle-class women spent their time in walking and riding, in playing at cards or otherwise, in visiting their friends and keeping company, conversing with their equals (whom they term gosseps) and their neighbours, and making merry with them at child-births, christenings,

1 Two letters from Cartwright to 'Mrs D.B.', Corpus Christi College, Oxford, MS 294, ff. 163-83; printed in part, Cartwrightiana, ed. Albert Peel, Elizabethan Nonconformist Texts, I (195I), I05-8.

${ }^{2}$ Edward Dering to Lady Elizabeth Golding, n.d., printed in Certaine godly and comfortable letters, in Dering's Workes, ${ }_{597}$, Sigs. $C_{7}-8 ;$ Lady Golding is identified from a copy of the letter in Dering's hand in the Kent Archives Office, Maidstone, MS Dering $\mathrm{U}_{350}, \mathrm{C}_{\mathrm{I}} / \mathrm{I}, \mathrm{f} .3$. I am indebted to the County Archivist of Kent, Dr Felix Hull, for permission to make several citations from the Dering Papers in his care.

- Various dedicatory epistles in Wilcox's published works; notes by Roger Morrice on a folio volume of Wilcox's letters in MS no longer extant, Dr Williams's Library, MS Morrice 'A Chronological Account of Eminent Persons,' 11, 617 (2), (4). 


\section{The Role of Women in the English Reformation}

churchings . . . and funerals; and all this with the permission and knowledge of their husbands, as such is the custom.' 1 The example of modern Islamic societies leads one to expect the enthusiastic, even violent adoption of political causes by a partially emancipated womanhood. Translated into sixteenth-century categories, we are perhaps witnessing something of the same sort in the vigorous religious partisanship of the women of that time. And in a society of arranged marriages, in which the wives nevertheless had leisure to cultivate religious neuroses and sufficient freedom to move outside the household, it is not to be wondered at if an intimate friendship with some physician of the soul was not seldom the result. A theme which creeps into some of these letters is this: 'Hath your husband beene unkind to you? Beare it and you shal winne him at the last; if not, thank God that you can continue loving and obedient even unto an unkind husband.' 2

One could speak of many godly matrons in Tudor England, but at this point I propose to leave generalities and to concentrate our attention on one, best known to posterity as Anne Locke, although she won a mention from Lady Stenton under the name of Anne Prowse. ${ }^{3}$ In all, this lady had four names, her own and those of her three husbands, and she might as well have borne a fifth, that of John Knox, for no one was ever closer to the Scottish reformer. In all these roles, and under all her names, the career of Mrs Locke has something of interest in it, and I propose to attempt what has not, I think, been done before, and draw her life together as a whole.

Anne Locke was the elder daughter of Stephen Vaughan, an entrepreneur and diplomatist of the reign of Henry VIII, whose diverse interests have been the subject of a recent monograph by Professor W. C. Richardson. ${ }^{4}$ Vaughan was the son of a London mercer and himself an active Merchant Adventurer. Common business interests seem to have drawn him into contact with Thomas Cromwell and a career in government service. From 1538 he was governor of the Merchant Adventurers' factory at Antwerp besides

1 W. B. Rye, England as Seen by Foreigners in the Days of Elizabeth and Fames the First, $1865,72$.

Edward Dering to Mrs Honeywood, r9 April n.y., Dering, op. cit. Sigs. C $2^{v}-3$; Mrs Honeywood identified from MS Dering U $350, \mathrm{CI} / \mathbf{r}$, f. 5 .

${ }^{8}$ D. M. Stenton, The English Woman in History, 1957, 136.

- Stephen Vaughan, Financial Agent of Henry VIII. A Study of FinancialRelations with the Low Countries, Louisiana State University Studies, Social Science Series, II, Baton Rouge 1953. 


\section{Studies in Church History-II}

acting, in effect, as the permanent financial agent for the English government from that time until $1546 .^{1}$ As for his religion, with one foot in Cromwell's entourage and another in the Antwerp trade, it is not surprising that Vaughan was moving in these years into a definitely protestant position, part of that largely unrecorded but highly significant process of conversion which was going forward steadily in the thirties and forties. In I 530 Vaughan had been sent to Flanders to persuade William Tyndale to return to England and bend his pen to the king's policies. Although, as he wrote in his own defence, 'neither Lutheran nor yet Tyndalin,' Vaughan's despatches show an utterly untheological mind predisposed to heresy, and one understands why he was regarded with enduring suspicion by Sir Thomas More. For his own faith, he wrote, 'I have the holy scripture, given to me by Christ's church, and that is a learning sufficient for me, infallible and taught by Christ.' When Tyndale was arrested in 1535 , Vaughan urged Cromwell to intervene to save his life. ${ }^{2}$ By 1546 there is very little doubt of what his religious profession had become. His first wife and the mother of his three children, a woman of some culture, 'witty and housewifely,' had died in the previous year, and he now sought 'a sad, trusty and womanly matron' to succeed her. He chose Margery Brinklow, the widow of the London mercer who had written that bitter and excessive diatribe, The Complaynt of Roderyck Mors. She brought him only a small estate, but Vaughan was content to quote Scripture: 'Riches is the gift of God, but an honest woman that feareth God is above all riches.' So the probability is that Anne Vaughan, now perhaps in her early teens, spent some of these most formative years in the care of a stepmother of uncompromising protestant profession. ${ }^{3}$

Stephen Vaughan died in the winter of $1549-50$, a substantial parishioner of St Mary Bow, Cheapside, leaving a twelve-year-old son, Stephen, and two daughters, Anne and Jane, who were older but still minors and unmarried. ${ }^{4}$ Some time in the next six years Anne was married to Henry Locke (or Lok), a mercer with interests in Antwerp and her father's neighbour in Cheapside. Locke came of a

1 Ibid. $\mathrm{r}-20 ; D . N . B$. art. Vaughan.

2 Richardson, op. cit. 25-34; J. F. Mozley, William Tyndale, 1937, 207-10.

? Richardson, op. cit. 21-2; Henry Brinklow's Complaynt of Roderyck Mors, ed. J. M. Cowper, Early English Text Society, Extra Series xxII, 1874; D.N.B. art. Brinklow.

4 Richardson, op. cit. 79, 23; Abstracts of Inquisitions Post Mortem Relating to the City of London, I, ed. George S. Fry, Index Library, 1896, 85-7; Principal Probate Registry, Somerset House, P.C.C. wills, 5 Coode. 


\section{The Role of Women in the English Reformation}

long line of mercers. His great-grandfather, John Locke, was sheriff of London in 1460 ; his father, Sir William Locke, who died in $155^{\circ}$, was a friend of Henry VIII and as sheriff helped to conduct Somerset to the Tower in October 1549. Another of Sir William's thirteen sons was Michael Lok, the famous traveller, a friend of Sir Martin Frobisher and an early adventurer in the Cathay and Levant Companies. ${ }^{1}$ Michael Lok's second wife was the widow of Caesar Adelmare and thus the mother of that highly successful Elizabethan official who took the name of Julius Caesar, so that Anne Locke was Caesar's aunt by marriage. ${ }^{2}$ The Lockes seem to have been Protestants from the generation of Sir William, and their numerous connections, many within the closed circle of their business associates, suggest that a study of early Protestantism in the Mercers' Company would prove rewarding. For example, Thomas Wood, the friend and companion of William Whittingham, later an elder at Geneva and an active member of the organised Puritan Movement in Elizabethan England, seems to have been a mercer and a factor to Henry Locke before his departure for Frankfurt in $1554 .{ }^{3}$ However, Henry Locke himself would appear to have been a somewhat formal Protestant, cast in another mould from that of his wife. The Lockes were also a cultivated family, and more than one of them had some literary pretensions. Michael Lok translated part of Peter Martyr's Historie of the West Indies. ${ }^{4}$ Henry Locke, Anne's husband, could write Latin in an elegant Italian hand, ${ }^{5}$ and their son, Henry Locke, was an indifferent religious poet, author of a pedestrian versification of Ecclesiastes, 'paraphristically dilated in English poesie' 6 and of two hundred religious sonnets, published in 1593 as Sundry Christian Passions, besides some scores of secular sonnets addressed to many late Elizabethan notables, with which he attempted to advance an equally unfruitful career as a courtier. ${ }^{7}$ His cousin, Michael

${ }^{1}$ D.N.B. arts. Sir William Locke, Henry Locke (the younger), Michael Lok.

In 1590, when Anne Locke was married to Richard Prowse of Exeter and Caesar Master of Requests, Prowse tried to exploit the relationship to assist a Chancery suit concerning a $f 20$ annuity which his wife claimed against ' $M r$ Locke, her adversarie'; B.M. MS Lansdowne 163 , f. 379 .

See my Letters of Thomas Wood, Puritan, $1566-1577$, Bulletin of the Institute of Historical Research, Special Supplement no. 5, November 1960 , iv.

- De Novo Orbe, or the Historie of the West Indies, 1612.

- An example of his calligraphy is noted on p. 266 below.

- Ecclesiastes, otherwise called The Preacher, 1597.

'Printed in Miscellanies of the Fuller Worthies' Library, Poems by Henry Lok, Gentleman, (1593-1597), ed. A. B. Grosart, 1871 . 


\section{Studies in Church History-II}

Cosworth, son of one of Sir William Locke's daughters married to yet another London mercer, contributed commendatory verses to Henry Locke's Ecclesiastes and himself turned the Psalms into English metre in a version which was widely circulated in MS. ${ }^{1}$ As we shall see, Anne Locke was not out of place in this family of pious poetasters.

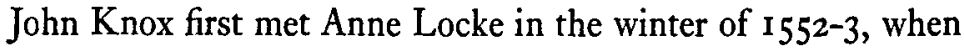
he wrote to his future mother-in-law, Mrs Elizabeth Bowes, from London and described himself sitting with 'thrie honest pure ${ }^{2}$ wemen,' sharing their infirmities and their tears. ${ }^{3}$ One of these may well have been Anne Locke, another the wife of a merchant called Hickman, and in the later months of ${ }_{553} \mathrm{Knox}$ was living with the Lockes and the Hickmans before his departure for the Continent. ${ }^{4}$ Most of Knox's biographers have had their say about his friendship with Mrs Locke, ${ }^{5}$ but none has handled it with more perception and tact than Robert Louis Stevenson in a little-known essay, 'John Knox and his Relations to Women.' ' Stevenson felt with some justification that Anne Locke was the woman that Knox loved best. She was pious and learned, and yet lacked the morbid scrupulosity which made Elizabeth Bowes a spiritual hypochondriac. Certainly, as Professor Croft Dickinson has remarked, Knox's letters to Mrs Locke reveal aspects of his character of which we should have remained in ignorance if they had never met. ${ }^{7}$ There are thirteen letters in the series, extending from $155^{6}$ until $\mathrm{r}_{562}$, and besides containing an eloquent memorial of Knox the man, the later letters carry valuable reports of events in Scotland after his return in 1559 .

The first letters were written by Knox in Geneva to Mrs Locke in London, and with the scarcely concealed motive of inciting her to leave her husband and family and to join God's saints in exile. In November ${ }^{1} 55^{6}$ he wrote: 'Ye wryt that your desyre is ernist to sie me. Deir Sister, yf I suld expres the thrist and langoure whilk I haif

${ }^{1}$ D.N.B. art. Cosworth.

I.e. poor.

Works of 7ohn Knox, ed. David Laing, 111 (1854), 379-80.

- Thomas McCrie, Life of Zohn Knox, 3rd ed., Edinburgh I814, I, II4.

s Perhaps the most discreet comment is that of Dr McCrie who represents Knox's letter inviting her to Geneva as having been written to 'Mr Locke.'

- Originally published in Macmillans Magazine, Sept. and Oct. 1875; reprinted in Familiar Studies of Men and Books, Tusitala ed. of the Works, xxvII, s.d., 202-44.

' Fohn Knox's History of the Reformation in Scotland, ed. William Croft Dickinson, I, lexxiii-lxxxv. 


\section{The Role of Women in the English Reformation}

had for your presence, I suld appeir to pass measure.' 1 In his next letter, written on 9 December, he attempted to draw her to Geneva with that classic phrase which has lost some of its original freshness for university teachers and examiners. In spite of her husband's opposition and 'so gud occasioun as God hath now offrit yow to remane whair ye ar,' Knox longed that it would please God 'to gyd and conduct your self to this place, whair I nether feir nor eschame to say is the maist perfyt schoole of Chryst that ever was in the erth since the dayis of the Apostillis.' 2 Five months later, on 8 May, Mrs Locke arrived in Geneva with two infants, Harrie and Anne, and a maid, but without her husband. Little Harrie was, of course, the future poet; Anne was buried within four days of their arrival. ${ }^{3}$ Mrs Locke's desertion of her husband for the cause of religion was not without parallel. Romier tells of a citizen of Nîmes whose wife had decamped to Geneva taking the portable assets of the household with her, and who complained to Calvin that plenty of other women would like to do the same, on the pretext that their protestant faith received no encouragement from their husbands. ${ }^{4}$ Anne Locke must have been an asset to the congregation of English exiles gathered in Geneva. Part of her time was spent in translating Calvin's sermons on the song of Hezekiah from Isaiah xxxviii, the first of her literary ventures to be published. This she dedicated to that intrepid adventurer and fellow-exile Catherine Bertie, dowager duchess of Suffolk. Discoursing elegantly on the diseases of the soul and their cure, a characteristic feminine theme, she wrote pleasantly: "This receipte God the heavenly Physitian hath taught, his most excellent Apothecarie Master John Calvine hath compounded, and I, your grace's most bounden and humble, have put into an Englishe box and do present unto you.' The sermons are followed by $A$ meditation of a penitent sinner, a metrical paraphrase of the fifty-first Psalm, perhaps Knox's work, which 'was delivered me by my frend with whom I knew I might be so bolde to use and publishe it as pleased me.' 5 A copy of this little volume in the British Museum ${ }^{6}$ bears on the

1 Laing, ed. cit. Iv (1864), 237-9.

Ibid. 239-4I.

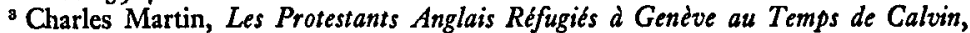
1555-1560, Geneva 1915, 64, 333, 338.

Romier, op. cit. 11, 236.

- Sermons of John Calvin upon the songe that Ezechias made after he had bene sicke and afficted by the hand of God, conteyned in the $3^{8}$ chapiter of Esay, London 1560 , Sig. A 3.; A meditation, sig. Ai.

- Press-mark 696.a.40. 


\section{Studies in Church History-II}

fly-leaf what is surely one of the most curious and touching comments on a sixteenth-century marriage partnership: 'Liber Henrici Lock ex dono Annae, uxoris suae, 1559.'

Knox left Geneva for the last time in January 1559 and within a month Mrs Locke was asking why he had not written and if he had already forgotten her. In April he wrote from Dieppe:

Of nature I am churlish, and in conditions different from many: Yet one thing I ashame not to affirme, that familiaritie once throughlie contracted was never yet brocken on my default. . However it be, as tuiching remembrance of yow, it cannot be, I say, the corporall absence of one year or two that can quenche in my hart that familiar acquaintance in Christ Jesus, which half a yeare did engender, and almost two yeares did nourish and confirme. ${ }^{1}$

This letter contained strangely ambiguous advice for a Geneva congregation uncertain whether or not to entrust itself to the inadequately reformed Church of Elizabeth. As Knox put it later: 'That we ought not to justifie with our presence such a mingle mangle as now is commaunded in your kirks,' but that those who stayed away 'onlie for negligence' were to be condemned. Mrs Locke herself had told Knox her own reasons for not 'assisting to their assemblie,' which Knox implied were rather superficial-objections to the surplice and 'external monuments of idolatrie.' But his rule for these problems of conscience was the same puritan maxim which she had so often heard from his mouth: 'That in the Lord's actioun nothing ought to be used that the Lord Jesus hath not sanctified, nather by precept nor by practise.' ${ }^{2}$ The next letter, of 3 May, came from Edinburgh, and the next, of 23 June, from St Andrews, and there were five more in the course of eight months, packed with reports of the rapidly developing Scottish scene. ${ }^{3} \mathrm{Knox}$ relied on Mrs Locke to pass on this news to other members of the Geneva congregation, and to convey messages to Christopher Goodman, Miles Coverdale, John Bodley, and others. It may or may not be significant that among the many personal messages which Knox channelled through Mrs Locke during the next three years-including more than one compliment to Michael Lok and his wife, whom Knox had never met-there is hardly a word for her husband.

Anne Locke was in Frankfurt in late March and was back in her

1 Laing, ed. cit. vI (1864), 1 I-I 5.

Ibid. 83-5.

Ibid. $21-7,30,83-5,100-1,103-4,107-9$. 


\section{The Role of Women in the English Reformation}

husband's house in Cheapside by mid-June I 559, when Knox wrote:

Communicate the contents heirof . . . with all faithfull, but especiallie with the afflicted of that little flock now dispersed, and destitute of these [sic] pleasaunt pastures in which they sometime fed abundantlie. If anie remaine at Geneva, lett ather this same, or the double of it be sent unto them, and likewise unto me deir brother, Mr Goodman. . .

In November he had further instructions: to send Calvin's latest works, including the last, definitive edition of the Institutes; and to influence the English faithful to send money for the support of the protestant army in Scotland-otherwise if we perishe in this our interprise, the limits of Londoun will be straiter than they are now within few yeeres.' 'I cannot weill write to anie other, because the actioun may seeme to appertaine to my countrie onlie.' In February I560 he wrote:

I know not what of our brethren of Geneva be with you; but to such as be there, I beseeche you to say that I think that I myself doe now find the truthe of that which oft I have said in their audience, to witt, that after our departure frome Geneva sould our dolour beginne.

In October $15^{6}$ I he sent her an early copy of the Scottish Confession of Faith, in quires, unbound; ${ }^{1}$ in May ${ }^{562}$, the last letter that we have. $^{2}$

With the end of this correspondence, we lose sight of Mrs Locke for more than ten years. During this period we can assume that she held a commanding and respected position among the London 'godly,' who began to earn the label of 'puritan' in the troubles about church ceremonies and discipline which began in 1566 . In 157 I her husband died after a lingering illness. His will ${ }^{3}$ bequeathed all his worldly goods to his wife and appointed her sole executrix. A woman of Anne Locke's qualities and substance was not allowed to remain a widow for long, and perhaps we should not be surprised that she now married, not another mercer, but the godliest and most promising young preacher of the day, Edward Dering, a successor, surely, to Knox rather than to Henry Locke. One of Dering's letters of proposal survives ${ }^{4}-$ no doubt the decisive one-and this is surely the

1 Ibid. 129-31.

Ibid. 140-1.

s Principal Probate Registry, Somerset House, P.C.C. wills, 39 Honey; made 28 January $1570 / 1$ when he was 'sicke and weake in bodie,' proved 31 October 1571.

'Kent Archives Office, Maidstone, MS Dering U 350, $\mathrm{CI} / 2, \mathrm{ff} .28^{v}-29^{r}$. The Dering Papers include two collections of Dering's letters ( $U$ 350, $\mathrm{Cr} / 1,2)$, most of which 


\section{Studies in Church History-II}

earliest extant document of this kind to have been penned by a clergyman of the Church of England. In it Dering mingles an obsessive puritan conscientiousness with more normal instincts and calculations in a way that I find utterly disarming, and Mrs Locke must have found it equally pleasing:

Thoughe I atempte nothyng but that which ys verye laufull and becomethe any Christian in plac and condition agreeable to every mane's estate, yet our nature is so full of nedeles shamfastnes that bothe nowe it makythe me almoste afearde to write unto you, and sync my last letters it hathe made me carefull to shunne your good companye.

He depended upon a trustworthy intermediary, 'Mysterys Martin,' to assure her of the state of his feelings. This Mrs Martin was probably the wife of Richard Martin, goldsmith and Master of the Mint, a notable Puritan who entertained Cartwright on the eve of his exile in 1573 . In the same year Mrs Martin was reported by Bishop Grindal to have been the stationer in her house in Cheapside for the first impression of Cartwright's Replie to John Whitgift's Answer to the Admonition. ${ }^{1}$ And in ${ }_{5} 5_{4}$ she would help to nurse one of the Scottish presbyterian ministers in exile in England through his last illness, lavishing on him expensive medicines, 'so careful was she of his health and restoring.' ' 'Yf God shall worke all that I desyre,' Dering went on, with rather more piety than tact,

it is nether the first nor the gretest benefit that I have receevid. Yf he shall worke otherwise, I trust his grac shall gide me that I shall accompte best of myne owne will when it is framed unto his. In this mynde, good Mysterys Locke, I write unto you as as [sic] before, sekinge you alone, whome the grace of God in myne opinion hathe made a good possescion, and my minde is so setled (and yet in the fear of God) that nether as I am I wolde remove it unto any, nether yet yf I were as highe as in the world I colde rise, I wold change it from you; and you shall do as the Lorde shall move you. Yf your affection shalbe enclyned as I doo wyshe it to be bent, God's name be praised. Yf you shall better like other where, I pray God blesse you. I wyll endure my losse under thys hope: when we shall have better eies that shalbe able to se God, our faythe shall lead us bothe into a happye societie. . . But for the worlde, I am at a pointe, and whensoever I shall thinke of you, I wyll think of you with the Lorde, where your body shalbe better. . . For the worldlye estate in which I

occur among the Godly and comfortable letters (earliest extant edition in Dering's Workes, 1597). The letter to Mrs Locke (which is undated) does not appear in the published collection.

1 Grindal, Remains, ed. cit. $347^{-8}$.

2 B.M. MS Additional 4736, f. $166^{v}$. 


\section{The Role of Women in the English Reformation}

hope to lyve, I will signyfie somwhat that you shall not thynk that I meane thoroughe me to make your estate or your childrene's the worse,

and he ends with an allusion to expectations from an elderly uncle. If Mrs Locke found this fervent preacher, perhaps ten years her junior, irresistible, so did a number of other ladies with whom she must always have had to share him: Lady Mary Mildmay, Lady Golding of East Peckham, Kent, Mrs Mary Honeywood, whose notorious spiritual hypochondria and enormous progeny and longevity won her a place in Fuller's Worthies, ${ }^{1}$ a Mrs Barrett of Bray, and above all Mrs Catherine Killigrew, one of the four learned daughters of Sir Anthony Cooke of Gidea Hall, who was Burghley's sister-in-law and Francis Bacon's aunt. Dering was often detained in the Killigrew household at Hendon. ${ }^{2}$ But Anne seems to have enjoyed her sisterly relationship with these other women who had their own claims on her husband's spiritual comforts. 'Mrs. $H$. and my wife wish to see you,' Dering wrote to Catherine Killigrew on one occasion. ${ }^{3}$

The first year of the Derings' married life can have brought them little peace. Dering was lecturing on the Epistle to the Hebrews at St Paul's, and was thought by some to be the most notable preacher of his day. ${ }^{4}$ But this was 1573 , the year after An Admonition to the Parliament had declared open war on the bishops from positions which Dering was helping to defend. In May Archbishop Parker and Bishop Sandys of London persuaded the Council to examine him in the Star Chamber and to sound him out on a set of twenty articles based on the arguments of Thomas Cartwright's Replie to John Whitgift's Answer to the Admonition. ${ }^{5}$ To Parker's exasperation, the Council did nothing effectual to stop Dering's lectures, but in December he was silenced at the Queen's personal command, in spite of Mrs Killigrew's efforts on his behalf. ${ }^{8}$ In the same month the Puritans generally, and especially in London, were subjected to a

1 Thomas Fuller, The History of the Worthies of England, 1662, II, 85-6.

2 Dering's correspondents appear as initials only in most of the Godly and comfortable letters, but are identified from the copies in MSS Dering $U$ 350, $\mathrm{CI} / \mathrm{I}, 2$ in the Kent Archives Office.

'Dering, op. cit. Sig. C 5. The printed text has 'Maister H.'; the correct reading is supplied from the Dering Papers.

- Correspondence of Matthem Parker, ed. John Bruce, Parker Society, 1853, 410.

- Inner Temple Library, MS Petyt 538/47, ff. 479-80.

- Parker Correspondence, ed. cit. 434; Acts of the Privy Council, ed. J. R. Dasent, viII (1894), 133; Dering, op. cit. Sigs. A 4-5. For fuller details of Dering's affairs in 1573 


\section{Studies in Church History-II}

vigorous campaign of repression announced in a royal proclamation. ${ }^{1}$ Not only ministers but laymen and women, 'such as they call Puritans,' were committed to prison in numbers on their refusal to subscribe. ${ }^{2}$ Dering told his brother on Christmas Eve: 'My wife hath beene I thanke God in no trouble, neyther was any toward her that I know of; if any fall, God hath made her rich in grace and knowledge to give account of her doing.' 3 But troubles of another kind were not far away. Dering was a consumptive and by the summer of 1575 he was spitting blood; he died a year later, on 26 June 1576 , aged thirty-six. ${ }^{4}$

Anne Locke's third and last marriage took her out of London and down to Devon. She married, some time before 1583 , Richard Prowse, an Exeter draper and a substantial figure in West Country affairs. Prowse was successively bailiff, sheriff, and alderman of Exeter, and mayor three times. He sat in Parliament in 1584 and showed a keen interest in anything which had to do with cloth. His son by his first marriage, John Prowse, was to be a very prominent Exeter M.P. Prowse was a godly gentleman, allied with other firm Devon Protestants, Carews and Periams. ${ }^{5}$ I have not followed Anne Locke down into the West Country and I have little to add on this last, more placid period of her life. But in 1583 an old friend from Geneva days, Christopher Goodman, appeared in Exeter and preached a controversial sermon in the cathedral, ${ }^{6}$ and I can think of nothing that would have drawn him so far from his usual haunts but Anne Locke. In any event there are two episodes left to describe which suggest that all the godly exhortation which Anne Locke had received was not in vain, and that the wife of the mayor of Exeter remained steadfast to the end.

see my Friends of Dr Williams's Library Annual Lecture (1963), A Mirror of Elizabethan Puritanism; the Life and Letters of 'Godly Master Dering.'

${ }^{1}$ Tudor and Stuart Proclamations, 1485-1714, ed. Robert Steele, 1910, 1, no. 689; Dasent, ed. cit. vIII, 140, 17 I.

${ }^{2}$ Letters of Thomas Wood, ed. cit. 6-8; Cambridge University Library, MS Mm.1.43, 44 r. Dering, opt. Sig. A 4 .

I Ibid. Sigs. C 3-7; A. F. Scott Pearson, Thomas Cartwright and Elizabethan Puritanism, ${ }_{5} 535-1603,1925,117$.

${ }_{5}^{5}$ J. C. Roberts, 'The Parliamentary Representation of Devon and Dorset, I559I601,' unpublished London M.A. thesis, 1958, unpaginated biographies; Hazel Matthews, 'Personnel of the Parliament of $1584-1585$,' unpublished London M.A. thesis, 1948, 183-4; Principal Probate Registry, Somerset House, P.C.C. wills, 83 Huddlestone, will of Richard Prowse, made 20 May 1607, proved Io November 1607.

- Albert Peel, 'A Sermon of Christopher Goodman's in 1583 ,' Fournal of the Presbyterian Historical Society of England, IX (1949), 90. 


\section{The Role of Women in the English Reformation}

In January ${ }_{15}{ }^{8} 3$ that restless opportunist John Field, commissar and propagandist of the organised Puritan Movement, published part of a minor work on the Temptations of Christ which Knox had sent to Mrs Locke in ${ }^{1556 .}{ }^{1}$ The MS had been in Field's possession for some time, but it was still unquestionably Mrs Locke's property and probably a treasured keepsake. No one was ever more eager than Field to record, gather, and publish anything which could conceivably help the cause of 'further Reformation,' and, as was his way, he published Knox's MS without asking leave, arguing that it was the common possession of the Church. In compensation he dedicated the volume to Mrs Prowse-seizing the opportunity to urge her to send any other Knoxiana which she might still possess:

And if by yourselfe, or others, you can procure any other his writinges or letters, here at home or abroad, in Scotland or in England, be a meane that we may receive them. It was great pittie that any the least of his writings should be lost. ... And his Letters, being had together, would together set out an whole Historie of the Churches where he lyved. ${ }^{2}$

This may explain how the Knox-Locke correspondence was preserved and found its way into Calderwood's History, which is the earliest text that can be traced. ${ }^{3}$ At least one of these letters was already known to Field (that which had accompanied the Exposition on the Temptations), ${ }^{4}$ and perhaps Mrs Prowse now parted with the rest. They would then have passed into the possession of the Scottish presbyterian ministers, Andrew Melville and others, who were exiles in England in $1584-5$. Some of these ministers held regular meetings that winter with Field in London and they were entertained by Anthony Martin and his sister-in-law, Mrs Martin, an old intimate of Anne Locke. ${ }^{5}$ Field went on to tell Mrs Prowse that he kept by him 'many of the writings, labors and letters of that worthy and godly man's, your late and deare husband, Mr Edward Dering (whom I name even for honor's sake) and gather them in dayly as I can get them, of his and my good friendes.' This tends to confirm what is clear from one or two of Dering's individual printed sermons: that Field was the editor of Dering's collected Workes as we have them

1 Reprinted in Knox's Works, ed, cit. IV, 85-1 I4.

Ibid. IV, 92.

Ibid. vi, 7.

- Ibid. IV, 92.

- A Seconde Parte of a Register, ed. Albert Peel, 1915, I, 284; B.M. MS Additional 4736 , f. $166^{2}$. 


\section{Studies in Churchistory-II}

in the 1597 edition. ${ }^{1}$ Although, as Field acknowledged, Mrs Prowse was 'no young scholler in [God's] school,' he ended with the exhortations which ladies like this, with their fearful trials and tearful temptations, expected to hear from a preacher of the Gospel. 'Remember the hope of your calling . . . strive on forwarde with good courage.' ${ }^{3}$

The last word comes in I590 when Anne Locke for the second time brought a work of her own to the press:

Everie one in his calling is bound to doo somewhat to the furtherance of the holie building, but because great things by reason of my sex I may not doo, and that which I may I ought to doo, I have according to my duetie brought my poore basket of stones to the strengthning of the walles of that Jerusalem whereof (by grace) wee are all both citizens and members.

Her basket contained a translation from the French of Jean Taffin, Of the markes of the children of God, and of their comfort in afflictions, solace originally intended for the oppressed Protestants of the Netherlands, but which Mrs Prowse believed would soon be needed in England. This was a time when Archbishop Whitgift and the High Commission were delivering a crippling blow to the Puritan Movement, if not to puritan religion, and in the epistle which presents her little book to another elderly lady of proven godliness, Ann, countess of Warwick, there is an old person's perspective: the good days-'Halcyon daies' she calls them-of Gospel liberty under Elizabeth are already passing, and nothing but trial lies ahead. ${ }^{3}$ I know of no earlier trace in literature of the retrospective legend of the Elizabethan golden age which was to be so emotive in seventeenth-century religion and politics, and perhaps for this reason the volume was reprinted in 1608 and 1634 . Thus Anne Locke's life spans the whole story of the Reformation in England, from Tyndale in the Netherlands and the Complaynt of Roderyck Mors to the post-Reformation atmosphere of the Stuart conflicts, which is dimly foreseen in this touching last testament.

'See my essay, 'John Field and Elizabethan Puritanism,' Elizabethan Government and Society: Essays Presented to Sir Fohn Neale, ed. S. T. Bindoff, J. Hurstfield and C. H. Williams, 196I, 144-5.

Laing, ed. cit. IV, 92-3.

3 Of the markes, Sigs. A $2-5^{v}$. 